\title{
Phytochemical constituents, nutritional values, phenolics, flavonols, flavonoids, antioxidant and cytotoxicity studies on Phaleria macrocarpa (Scheff.) Boerl fruits
}

\author{
Ma Ma Lay ${ }^{1 *}$, Saiful Anuar Karsani ${ }^{1,2}$, Sadegh Mohajer ${ }^{1}$ and Sri Nurestri Abd Malek ${ }^{1}$
}

\begin{abstract}
Background: The edible fruits of Phaleria macrocarpa (Scheff.) Boerl are widely used in traditional medicine in Indonesia. It is used to treat a variety of medical conditions such as - cancer, diabetes mellitus, allergies, liver and heart diseases, kidney failure, blood diseases, high blood pressure, stroke, various skin diseases, itching, aches, and flu. Therefore, it is of great interest to determine the biochemical and cytotoxic properties of the fruit extracts.

Methods: The methanol, hexane, chloroform, ethyl acetate, and water extracts of $P$. macrocarpa fruits were examined for phytochemicals, physicochemicals, flavonols, flavonoids and phenol content. Its nutritional value (A.O.A.C method), antioxidant properties (DPPH assay) and cytotoxicity (MTT cell proliferation assay) were also determined.

Results: A preliminary phyotochemical screening of the different crude extracts from the fruits of $P$. macrocarpa showed the presence secondary metabolites such as of flavonoids, phenols, saponin glycosides and tannins. The ethyl acetate and methanol extracts displayed high antioxidant acitivity $\left(I_{50}\right.$ value of $\left.8.15 \pm 0.02 \mathrm{ug} / \mathrm{mL}\right)$ in the DPPH assay comparable to that of the standard gallic acid $\left(I_{50}\right.$ value of $\left.10.8 \pm 0.02 \mathrm{ug} / \mathrm{mL}\right)$. Evaluation of cytotoxic activity showed that the crude methanol extract possessed excellent anti-proliferative activity against SKOV-3 $\left(\mathrm{IC}_{50} 7.75 \pm 2.56 \mu \mathrm{g} / \mathrm{mL}\right)$ after 72 hours of treatment whilst the hexane and ethyl acetate extracts displayed good cytotoxic effect against both SKOV-3 and MDA-MB231 cell lines. The chloroform extract however, showed selective inhibitory activity in the breast cancer cell line MDA-MB231 $\left(\mathrm{IC}_{50} 7.80 \pm 1.57 \mathrm{\mu g} / \mathrm{mL}\right)$ after 48 hours of treatment. There was no cytotoxic effect observed in the Ca Ski cell line and the two normal cell lines (MRC-5 and WRL-68).

Conclusion: The methanol extract and the ethyl acetate fraction of $P$. macrocarpa fruits exhibited good nutritional values, good antioxidant and cytotoxic activities, and merits further investigation to identify the specific compound(s) responsible for these activities.
\end{abstract}

Keywords: Cytoxicity, Phytochemicals, Nutritional values, Flavonoids, Flavonol, Phenol, Antioxidants, Phaleria macrocarpa (Scheff.) Boerl fruits or P. macrocarpa

\section{Background}

Medicinal plants can be found worldwide. However, they are most abundant in tropical regions. Classifying medicinal plants systematically is important in order to understand and study them extensively and efficiently. The Phaleria macrocarpa (Scheff) Boerl plant (local name mahkota

\footnotetext{
*Correspondence: mamalayster@gmail.com

${ }^{1}$ Institute of Biological Sciences, Faculty of Science, University of Malaya, 50603 Kuala Lumpur, Malaysia

Full list of author information is available at the end of the article
}

dewa) is a medicinal plant that originated from Yogyakarta, Indonesia. The fruits of $P$. macrocarpa have bright red skin, with fruit flesh, shells and seeds located inside the fruit. It has a smooth surface, is round in shape, with sizes ranging from 3-5 cm. It is a drill green color when young and changes to red once ripened. The fruit grows on the trunks and branches of trees with very short stalks. It looks like it is attached to the stem and also has white flesh, and is fibrous and watery. 
The major components of $P$. marcrocapa fruits are flavonoids. It also contains alkaloids, saponins, tannins, and terpenoids. The $\mathrm{n}$-hexane extract of $P$. macrocarpa fruits' flesh contains terpenoids, whereas the ethanol extract of $P$. macrocarpa flesh and seed fruit is composed of alkaloids, flavanoids, and triterpenoids [1]. It has also been shown that the $P$. macrocarpa fruits' flesh ethyl acetate extract contained flavonoids, triterpenoids and coumarin groups [2].

The fruits of $P$. macrocarpa are most often used in traditional medicine by mixing with other ingredients. It is used to treat a wide variety of diseases such as cancer, diabetes mellitus, allergies, liver and heart diseases, kidney failure, blood diseases, hypertension, stroke, various skin diseases, itching, aches and flu $[3,4]$. The fruits of $P$. macrocarpa is also likely to possess antimicrobial properties due to the presence of flavonoid compounds [5]. Moreover, a study that examined the effects of mahkota dewa treatment in diabetic animals showed that it was able to decrease the blood glucose level in these animals [6]. Sugiwati reported that extracts of young and ripe fruits of $P$. macrocarpa possessed inhibitory activity against in vitro $\alpha$-glucosidase [7]. In a separate study, it was shown that methanol extracts caused anti-nephropathic action [8]. The ethanol extract of $P$. macrocarpa fruit flesh has been found to be toxic towards the Hela cell line [9].

In the present study, the methanol, hexane, chloroform, ethyl acetate, and water extracts of $P$. macrocarpa fruits were examined for phytochemicals, flavonols, flavonoids, phenol content. Its nutritional values (A.O.A.C method), antioxidant activities (DPPH assay) and cytotoxicity (MTT cell proliferation assay) was also determined.

\section{Methods}

Plant material

Phaleria macrocarpa (Scheff.) Boerl plant meterials were collected from Gowongan Rd., Yogyakarta, Java, Indonesia. A voucher specimen (ID no: KLU 47923) was deposited into a repository at the Rimba Ilmu, Institute of science biological, Faculty of Science, University of Malaya, Malaysia. P. macrocarpa fruits were thoroughly washed with fresh water, sliced and dried in an oven at a temperature of no more than $50^{\circ} \mathrm{C}$. It was then ground into a fine powder. The dry, finely powdered samples were stored in airtight containers.

\section{Extraction}

The powdered $P$. macrocarpa fruits $(1 \mathrm{~kg})$ were soaked in $70 \%$ aqueous methanol for three days at room temperature and then filtered to recover the supernatant. The filtrate was then re-filtered and poured into a roundbottomed flask and was evaporated at a low pressure $\left(60 \mathrm{rpm}\right.$ at $37^{\circ} \mathrm{C}$ ) to remove excess methanol. This resulted in a dark-brown coloured, concentrated crude methanol extract.

The methanol extract was then further fractionated with hexane. The hexane-insoluble residue was extracted with chloroform resulting in a chloroform-soluble fraction and a chloroform-insoluble residue. It was then filtered using filter paper and subjected to evaporation under pressure to remove excess solvent. The chloroform-insoluble fraction was then partitioned between ethyl acetate and water. A mixture of ethyl acetate and water (1:1) was prepared and poured into the round-bottomed flask containing the hexane-insoluble extract. It was then filtered using filter paper and subjected to evaporation under pressure to remove excess solvent. The methanol extract and its fractions were removed, placed in a vial, and kept in a refrigerator for further bioactivity assay.

\section{Phytochemical analysis}

The phytochemical constituents of $P$. macrocarpa fruits were determined using chemical methods and by adopting standard protocols as described by Harborne and Evans [10,11].

\section{Physicochemical determination}

Various nutritional values such as moisture, protein, fat, fiber, ash, carbohydrate and sugar contents of the dried, powdered $P$. macrocarpa fruits were determined using the following protocols.

\section{Moisture determination}

The moisture content of the samples was determined by drying $10 \mathrm{~g}$ of the sample in an air oven at $105^{\circ} \mathrm{C}$ until constant weight (16-18 h) was achieved [12]. The crucible containing the dried sample was weighed again and the weight loss was recognized as the moisture content of the dried powdered $P$. macrocarpa fruits. The experiment was repeated three times. The moisture content (\%) was calculated by using the following equation:

$$
\text { Moisture percentage }(\%)=\frac{\mathrm{W}_{2}-\mathrm{W}_{1}}{\mathrm{~W}_{0}} \times 100
$$

Where, $\mathrm{W}_{1}$ = weight of sample after drying $(\mathrm{g}), \mathrm{W}_{2}=$ weight of sample before drying $(\mathrm{g})$,

$$
\mathrm{W}_{0}=\text { weight of the sample }(\mathrm{g})
$$

\section{Protein determination}

Protein content was determined by using the A.O.A.C method [13]. Briefly, powdered P. macrocarpa fruit samples $(1 \mathrm{~g}), 50 \mathrm{~mL}$ of distilled water, $5 \mathrm{~g}$ of copper sulphate, and $15 \mathrm{~mL}$ of concentrated sulphuric acid were added into a Kjeldahl flask. The flask was partially closed by means of a funnel and the contents were digested by heating the flask at an inclined position in the digester. 
The mixture was heated for approximately 30 minutes until its volume was reduced to $40 \mathrm{~mL}$. Standard sulphuric acid $(0.1 \mathrm{M})$ and a few drops of methyl red indicator were added to the clear solution. The flask was then placed below a condenser and the end of the adapter tube was dipped in the acid. Kjeldahl distillation apparatus was set up and $70 \mathrm{~mL}$ of $40 \%$ sodium hydroxide was added through the funnel. The funnel was then washed twice with $50 \mathrm{~mL}$ of distilled water and distillation was performed for one hour. The distilled ammonia was nitrated with $0.1 \mathrm{M}$ standard solution until the color changed from yellow to colorless. The experiment was repeated three times. The nitrogen content and protein content in the sample was calculated by using the following relation.

$$
\text { Percentage of Nitrogen }(\%)=\frac{\left(\mathrm{V}_{\mathrm{s}}-\mathrm{V}_{\mathrm{b}}\right) \times \mathrm{M}_{\mathrm{A}} \times 0.140 \times 100}{\text { Weight of sample }(\mathrm{W})}
$$

Protein content $=$ percentage of Nitrogen $\times 6.25 \mathrm{r}$

Where, $\mathrm{V}_{1}=$ volume in $\mathrm{cm}^{3}$ of standard acid used in the titration of sample, $\mathrm{V}_{2}=$ volume in $\mathrm{cm}^{3}$ of standard acid used in the blank titration, $\mathrm{M}_{\mathrm{A}}=$ molarities of standard acid solution in $\mathrm{mol} \mathrm{dm} \mathrm{dm}^{-3}, \mathrm{~W}=$ weight of the sample in grams.

\section{Fat content determination}

Fat content was determined using the soxhlet extraction method [13]. Briefly, the powdered P. macrocarpa fruits $(10 \mathrm{~g})$ were placed in a cotton bag which was then placed in a soxhlet extractor. Petroleum ether was then poured into the soxhlet extractor and the extraction was allowed to proceed for 12 hours. After the extraction was complete, excess petroleum ether was removed by distillation until the volume was reduced to about $15 \mathrm{~mL}$. The residual petroleum ether removed by drying at $105^{\circ} \mathrm{C}$ in an oven until constant weight was obtained. The experiment was repeated three times. The fat content was then calculated by using the following equation:

$$
\% \text { of Fat content }=\frac{\text { Weight of fat obtain from sample } \times 100}{\text { Weight of sample }}
$$

\section{Crude fiber determination}

Crude fiber content was determined according to the A. O.A.C method [13]. Briefly, dried powdered samples were accurately weighed and placed into a conical flask. Hot sulphuric acid (200 mL, 1.25\%) was added and the mixture was boiled for half an hour. Water was added to maintain a constant level. The mixture was then filtered and washed with distilled water. The residue was transferred into a flask with $200 \mathrm{~mL}$ of sodium hydroxide solution (1.25\%). It was then gently boiled for half an hour. Water was continuously added into the flask to maintain a constant level. The residue was then filtered and washed with boiling water until neutral $\mathrm{pH}$ was achieved. It was then washed with alcohol and ether and then dried in an oven at $100^{\circ} \mathrm{C}$ until constant weight was achieved. The fiber content was calculated by using the following equation:

$$
\text { Percentage of Crude fiber }(\%)=\frac{\text { Loss in weight }}{\text { Weight of sample }} \times 100
$$

\section{Ash determination}

Ash determination was performed as described by the A. O.A.C method [13]. Briefly, five grams of the dried, powdered sample was weighed in a crucible and then placed in a furnace at $500^{\circ} \mathrm{C}$ until the substance turned into ash. The crucible was then cooled in a desiccator and weighed. The procedure was repeated until a constant weight was obtained and the percentage of the total ash was calculated using the following formula [14]:

$$
\text { Percentage of Ash }(\%)=\frac{\text { Weight of Ash }}{\text { Weight of sample }} \times 100
$$

\section{Carbohydrate determination}

Carbohydrate content can be calculated by multiplying reducing sugar content by a factor of 0.9 . The reducing sugar content was determined using the Fehling's reducing method of Lane and Eynon [15]. Weighed samples were placed into $250 \mathrm{~mL}$ round-bottomed flasks. Sulphuric acid was then added $(20 \mathrm{~mL}, 0.5 \mathrm{M})$. Reflux was then performed in a sand bath for 2.5 hours. The flask was then cooled and its content filtered with filter paper. The resulting residue was washed with warm distilled water (a total of $100 \mathrm{~mL}$ ). A total of $10 \mathrm{~mL}$ of the solution was then neutralized with sodium carbonate. The mixture was topped up to $100 \mathrm{~mL}$ with distilled water. Fehling's solution $(5 \mathrm{~mL})$ was placed into a flask, followed by $5 \mathrm{~mL}$ of distilled water. The solution was boiled for 15 seconds. Several drops of methylene blue indicator was then added and titrated with the sample solution until the color changed from blue to green. The carbohydrate content was then calculated according to the following equation:

Percentage of carbohydrate content $(\%)=\frac{5 \times 0.005 \times 100 \times 100}{\mathrm{~V} \times 10 \times \mathrm{W}} \times 0.9 \%$

Where, $\mathrm{V}=$ volume of sample solution (titration volume), $\mathrm{W}=$ weight of powdered sample

\section{Reducing sugar determination}

Reducing sugar content was determined using the Lane and Eynon titration method [15]. Sample (1 g) was placed in $200 \mathrm{~mL}$ of distilled water and shaken for 30 minutes and filtered. Fehling's A (10 mL) solution and Fehling's B $(10 \mathrm{~mL})$ solution were poured into a flask. The sample 
filtrate $(20 \mathrm{~mL})$ and distilled water $(10 \mathrm{~mL})$ were then added. The solution was mixed thoroughly, boiled for 5 minutes, and cooled down to room temperature in an ice bath. This was followed by the addition of $10 \mathrm{~mL}$ of $30 \%$ potassium iodide solution, $10 \mathrm{~mL}$ of $20 \%$ sulfuric acid solution and $1 \mathrm{~mL}$ of starch indicator solution. Titration was then performed until the blue starch-iodine color disappeared. Reducing sugar content was calculated using the following formula:

$$
\begin{aligned}
\text { Percentage of reducing sugar }(\%)= & \frac{\times 200 \mathrm{ml}}{\text { Sample wt }(\mathrm{g}) \times 20 \mathrm{ml} \times 1000 \mathrm{mg} / \mathrm{g}} \\
& \times 100
\end{aligned}
$$

\section{Phenol determination}

The total phenol content of the crude methanol extract and its fractions (hexane, chloroform, ethyl acetate, and water) were determined using the Folin-Ciocalteau method with slight modification [16-19]. Briefly, $200 \mu \mathrm{l}$ $(20 \mathrm{mg} / \mathrm{mL})$ of each sample was added to $1 \mathrm{~mL}$ of $10 \%$ Folin-Ciocalteu reagent and $800 \mu \mathrm{L}$ of $7.5 \% \mathrm{Na}_{2} \mathrm{CO}_{3}$ solution. The mixture was shaken for five minutes and then incubated at $37^{\circ} \mathrm{C}$ for 15 minutes, followed by incubation in the dark for $1 \mathrm{hr}$. Absorbance was then measured at $760 \mathrm{~nm}$ against distilled water as a blank. Gallic acid was used to construct a standard curve. The amount of total phenol content was calculated as $\mathrm{mg} / \mathrm{g}$ gallic acid equivalent (GAE). For the gallic acid, the curve of absorbance versus concentration was described by the equation $y=0.00138 x-0.00247\left(R^{2}=0.923\right)$, where, $\mathrm{y}=$ absorbance and $\mathrm{x}=$ concentration [20]". The Total phenolic content of extracts and fractions of P. macrocarpa fruits was calculated using the following formula: Total phenol content $=\mathrm{GAEx} \mathrm{V} / \mathrm{m}$. Where GAE is the gallic acid equivalence $(\mathrm{mg} / \mathrm{mL}) ; \mathrm{V}$ is the volume extract $(\mathrm{mL})$ and $\mathrm{m}$ is the weight $(\mathrm{g})$ of the pure plant extract.

\section{Flavonoid determination}

The total flavonoid content of the methanol extract of $P$. macrocarpa and its fractions was measured as previously described, with modifications [16,21,22]. Briefly, $1 \mathrm{~mL}$ of sample $(1 \mathrm{mg} / \mathrm{mL})$ was poured into a centrifuge tube. This was followed by the addition of $0.1 \mathrm{~mL}$ of $10 \% \mathrm{Al}$ $\left(\mathrm{NO}_{3}\right)_{3}$ solution, $0.1 \mathrm{~mL}$ of $1 \mathrm{M}$ potassium acetate, and $3.8 \mathrm{~mL}$ of methanol. The content of the centrifuge tube was then mixed thoroughly with a vortex mixer for two to three minutes and allowed to stand for 10 minutes at room temperature. Absorbance was then measured at $410 \mathrm{~nm}$. Quercetin was used as a standard compound for the quantification of total flavonoids. Total flavonoid content was calculated as quercetin equivalent $(\mathrm{mg} / \mathrm{g})$ using the equation obtained from the curve $Y=0.0869 x+0.15$, $\mathrm{R}^{2}=0.9684$, where $\mathrm{X}$ is the absorbance and $\mathrm{Y}$ is the quercetin equivalent. The amount of flavonoids in the sample in quercetin equivalents was calculated using the formula: $\mathrm{X}=\left(\mathrm{A} \times \mathrm{m}_{0} \times 10\right) /\left(\mathrm{A}_{0} \times \mathrm{m}\right)$. Where: $\mathrm{X}=$ flavonoid content, mg quercetin/g; $A=$ the absorbance of sample; $A 0=$ the absorbance of standard quercetin.

\section{Flavonol determination}

The method of Kumaran and Mbaebie [23,24] with slight modification was used to measure the total flavonol content. Briefly, $1 \mathrm{~mL}$ of extract or fractions $(1 \mathrm{mg} / \mathrm{mL})$ was added to a centrifuge tube with $2 \mathrm{~mL}$ of $\mathrm{AlCl}_{3}$ prepared in ethanol and $3 \mathrm{~mL}$ of $50 \mathrm{~g} / \mathrm{L}$ sodium acetate solution. This was then mixed thoroughly with a vortex mixer and incubated for 1 hour. Absorbance was then measured at $440 \mathrm{~nm}$ with a spectrophotometer. Total flavonol content was calculated as quercetin equivalent $(\mathrm{mg} / \mathrm{g})$ using the following equation based on the calibration curve $\mathrm{Y}=0.0297 \mathrm{x}+0.1288, \mathrm{R}^{2}=0.9729$, where $\mathrm{X}$ is the $\mathrm{ab}-$ sorbance and $\mathrm{Y}$ is the quercetin equivalent. $\mathrm{X}=(\mathrm{A} \times$ $\left.\mathrm{m}_{0} \times 10\right) /\left(\mathrm{A}_{0} \times \mathrm{m}\right)$.Where: $\mathrm{X}=$ flavonoids content, $\mathrm{mg}$ quercetin/g; $\mathrm{A}=$ the absorbance of sample; $\mathrm{A} 0=$ the absorbance of standard quercetin.

\section{Antioxidant determination of DPPH assay}

DPPH (1, 1 Diphenyl -1- picrylhydrazyl) has a free radical that tends to capture hydrogen from antioxidants. Due to its free radical, the methanolic DPPH is violet and absorbs at $517 \mathrm{~nm}$. Antioxidant activity screening of P. macrocarpa fruit extract and fractions was carried out by determining the DPPH free radical scavenging property using the UV spectrophotometric method [21,25]. Briefly, $50 \mu \mathrm{L}$ of test solutions (different concentrations from dry extracts) were dissolved in water and added to $1.95 \mathrm{~mL}$ of $\mathrm{DPPH}$ in methanol. The mixtures were vortex-mixed and kept at room temperature, in the dark, for 30 minutes. The increase in absorbance was recorded at $517 \mathrm{~nm}$. Methanol was used as a blank, methanol and $\mathrm{DPPH}$ solution was used as a negative control (A0), and gallic acid, a standard phenolic compound, was used as a positive control. The antioxidant activity was represented as $\mathrm{IC}_{50}$. The antioxidant activity was determined as the final concentration of the tested sample required for the prevention of the generation of DPPH radical by $50 \%$ [26]. The $\mathrm{DPPH}$ radical concentration was calculated using the following equation:

$$
\text { Scavenging effect }(\%)=\frac{(\mathrm{A} 0-\mathrm{A} 1) \times 100}{\mathrm{~A} 0}
$$

Where, A0 was the absorbance of the control reaction and $\mathrm{A} 1$ was the absorbance in the presence of the tested extracts. The $\mathrm{IC}_{50}$ (concentration providing 50\% inhibition) was calculated graphically using a calibration curve in the linear range by plotting the extract concentration versus the corresponding scavenging effect [26]. 


\section{In Vitro cytotoxicity screening}

\section{Cancer cell lines and culture medium}

In this study, Ca Ski (human cervical carcinoma cell line), MCF-7 (human hormone-dependent breast carcinoma cell line), HT-29 (human colon carcinoma cell line), SKOV-3 (human ovarian carcinoma cell line), and MDAMB231 (human hormone dependent breast carcinoma cell line) were obtained from the American Tissue Culture Collection (ATCC, U.S.A). The cells were cultured and routinely maintained in RPMI 1640 medium for the CasKi, MCF-7 and HT-29 cells lines, and in Dulbecco's Modified Eagle's medium (DMEM, Sigma) for the SKOV3 and MDA-MB231 cell line. They were supplemented with $10 \%$ fetal bovine serum, $100 \mu \mathrm{g} / \mathrm{mL}$ penicillin or streptomycin $(\mathrm{P} / \mathrm{S})$, and $50 \mu \mathrm{g} / \mathrm{mL}$ of kanamycin/ amphotericin B. Cell cultures were incubated at $37^{\circ} \mathrm{C}$ in a humidified atmosphere containing $5 \% \mathrm{CO}_{2}$. The culture was sub-cultured every two to three days and routinely checked under an inverted microscope (Leica, Germany) for any contamination.

\section{MTT cell proliferation assay}

By using MTT (3, 4, 5-dimethylthiazol-2-yl)-2-5-diphenyltetrazolium bromide) assay, cell viability was determined. This assay was based on the reduction of MTT by the mitochondrial dehydrogenase of intact cells to a purple formazan product as described by the methods of Denizot and Mosmann [27,28]. Briefly, cells from a confluent tissue culture flask were spun at 1,000 rpm for 5 minutes and re-suspended with $1.0 \mathrm{~mL}$ of growth medium. The density of the viable cells was then determined using $0.4 \%$ of trypan blue exclusion dye in a haemocytometer with a microscope. The cells were then seeded into the wells of a microtiter plate and incubated in a $\mathrm{CO}_{2}$ incubator at $37^{\circ} \mathrm{C}$ for 24 hours in order to allow the cells to adhere and achieve 70 - 80\% confluence. After 24 hours, the media for each extract (different concentrations - 1, 10, 25, 50 and $100 \mu \mathrm{g} / \mathrm{mL}$ ) were removed and $200 \mathrm{~mL}$ of $10 \%$ media were added into the respective wells containing the cells. The assay was carried out in triplicate. Wells with untreated cells were used as the negative control. After incubation, MTT $(10 \mathrm{~mL})$ was added to each well [29]. The amount of formazan produced was determined by measuring absorbance at $540 \mathrm{~nm}$ using an ELISA micro plate reader.

The percentage of inhibition (\%) was calculated according to the following formula:

$$
\text { Percentage of inhibition }(\%)=\frac{\text { OD control-OD sample } \times 100 \%}{\text { OD control }}
$$

Cytotoxicity was expressed as an $\mathrm{IC}_{50}$ value. The $\mathrm{IC}_{50}$ value is the concentration of test compounds that causes $50 \%$ inhibition or cell death. The averaged values from three experiments were considered and the percentages of inhibition versus concentration of test compounds were plotted. The extract that gave an $\mathrm{IC}_{50}$ value of $30 \mu \mathrm{g} / \mathrm{mL}$ or less was considered active [27].

\section{Statistical analysis}

All data was subjected to statistical analysis by analysis of variance (ANOVA). Data from the three different time points, five cell lines and five different concentrations were analyzed in a combined analysis. For the determination of which concentration was most effective and which cell lines were most affected, a mean comparison was performed in DMRT Duncan (Duncan's multiple range test). In addition, advanced SAS 9.2 and Minitab 16.2 software system were also used for analyzing data.

\section{Results}

\section{Extraction}

P. macrocarpa fruits were collected in Yogyakarta, Indonesia in 2009. From the air-dried and finely milled samples (1000 g of fruits) hexane, chloroform, ethyl acetate and water extraction were performed sequentially. The extracts were concentrated using a rotary evaporator (Buchi, USA) under reduced pressure at $35^{\circ} \mathrm{C}$. Dried extracts were stored at $-4^{\circ} \mathrm{C}$. A diagrammatic representation of the extraction and fractionation carried out on Phaleria macrocarpa (Scheff.) Boerl fruits are shown in Figure 1.

The percentage of crude methanol extract yield was derived from the weight of dried and ground plant material. The hexane extract provided the lowest yield (0.20\%) for followed by the chloroform extract $(0.43 \%)$ as shown in Table 1.

\section{Quantitative physicochemical screening of $P$. macrocarpa fruits}

The determination of nutritional values such as moisture, ash, fibre, protein, fat and carbohydrate was carried out using AOAC and, the Lane and Eynon titration methods and the results obtained are shown in Table 2 and Figure 2 (a). Different physicochemical parameters such as moisture content $(13.21 \pm 2.13 \%)$, total ash $(5.24 \pm 1.56 \%)$, proteins $(8.51 \pm 1.99 \%)$, crude fibre $(38.77 \pm 3.01 \%)$, crude fat $(1.25 \pm 2.65 \%)$, carbohydrate $(33.02 \pm 1.72 \%)$ and sugar $(5.57 \pm 1.49 \%)$ were determined.

Preliminary phytochemical analysis on $P$. macrocarpa fruits In order to deterine the types of phyto-organic constituents present in the fruits of $P$. macrocarpa, phytochemical investigation was carried out according to conventional methods, and the results obtained from these experiments are summarized in Table 3.

The phytochemical tests showed that secondary metabolites such as flavonoids, glycosides, saponin glycosides, phenolic compounds, steroids, tannins, and terpenoids 


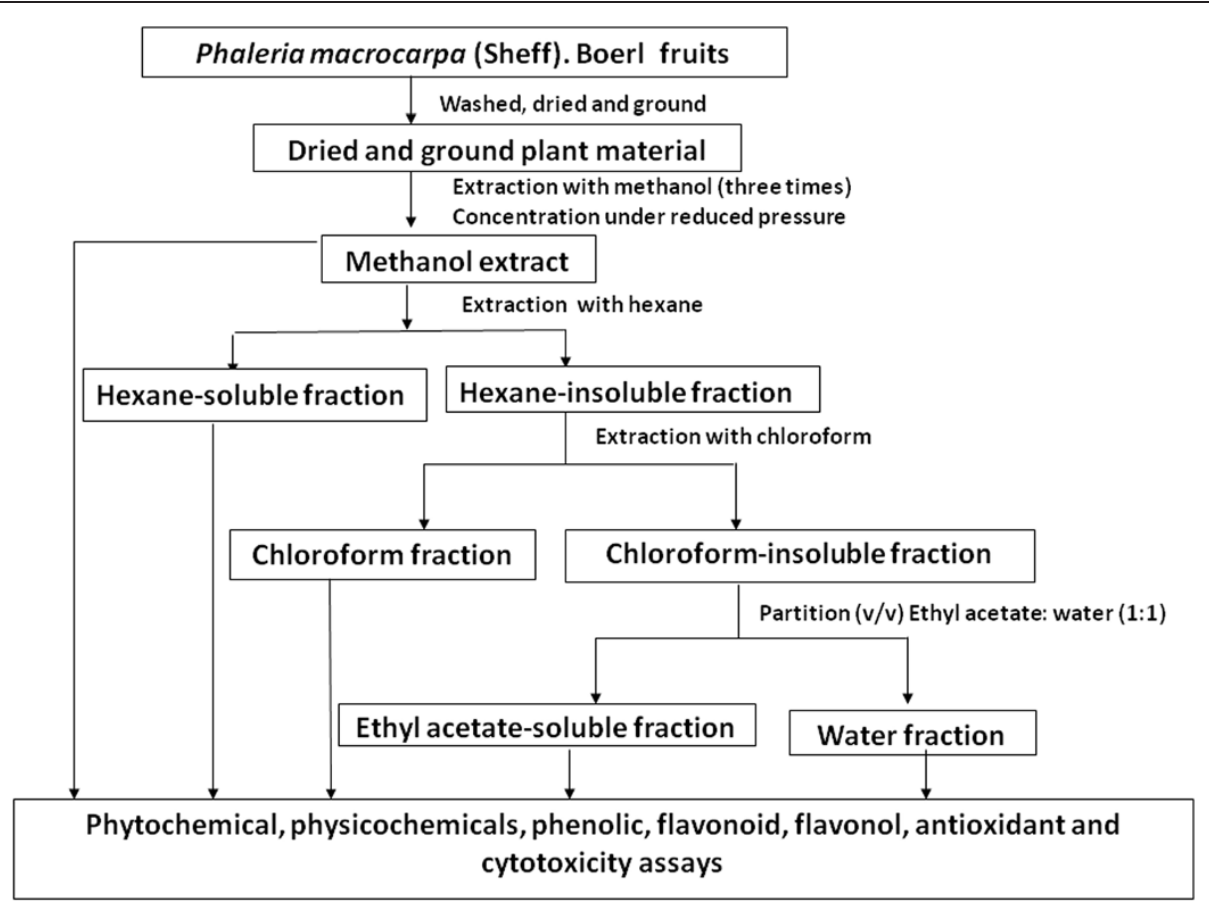

Figure 1 Summary of extraction and fractionation procedures of Phaleria macrocarpa (Scheff.) Boerl fruits.

were present in different extracts of $P$. macrocarpa fruits. Alkaloids, $\alpha$-amino acids, organic acids, reducing sugars and starch were found to be present in low amounts.

The high amount of phytochemical constituents such as flavonoids (major component), glycosides, saponin glycosides, phenolic compounds, tannins, and terpenoids present in the fruits of $P$. macrocarpa may contribute to the plant's bioactivities such as anti-oxidant and cytotoxic properties. In addition, there were also medium amounts of carbohydrates, steroids and terpenoids present in the fruits of $P$. macrocarpa.

\section{Flavonoid, flavonol and phenol determination}

In our study, it was found that the methanol extract had the highest flavonoid content which was $15.62 \pm 0.9 \mathrm{mg}$,

Table 1 Yield of methanol extract and its fractions (hexane, chloroform, ethyl acetate and water) from $P$. macrocarpa fruits

\begin{tabular}{ccc}
\hline Extract and fractions & Yield $(\mathbf{g})$ & Percentage of yield \\
\hline Methanolic extract & $47.2^{\mathrm{a}}$ & 4.7 \\
Hexane fraction & $2.1^{c}$ & 0.20 \\
Chloroform fraction & $3.1^{c}$ & 0.31 \\
Ethyl acetate fraction & $12.2^{\mathrm{b}}$ & 1.22 \\
Water fraction & Freez dry & \\
\hline
\end{tabular}

The means of the yield with same small letters were not significantly different as per Duncan's multi-range test at $P<0.05$. followed by ethyl acetate, water, chloroform and hexane fractions, which were $13.11 \pm 0.8,8.91 \pm 0.5,7.04 \pm 1.1$ and $4.98 \pm 0.6 \mathrm{mg}$ respectively.

The methanol extract of $P$. macrocapa fruits exhibited the highest amount $(14.75 \pm 1.5 \mathrm{mg} / \mathrm{mL})$ of total flavonol content, followed by water, ethyl acetate, chloroform and hexane fractions, which were $13.84 \pm 1.2,13.6 \pm 1.6$, $12.46 \pm 1.1$ and $8.32 \pm 1.8 \mathrm{mg} / \mathrm{mL}$.

The total phenolic content was reported as gallic acid equivalents. The methanol extract of $P$. macrocarpa fruits had the highest total phenol content $(16.54 \pm 1.5 \mathrm{mg} / \mathrm{mL})$, followed by the ethyl acetate fraction $(15.46 \pm 0.4 \mathrm{mg} / \mathrm{mL})$ and water fraction $(14.15 \pm 1.9 \mathrm{mg} / \mathrm{mL})$. The chloroform $(7.20 \pm 0.7 \mathrm{mg} / \mathrm{mL})$ and hexane fractions $(5.75 \pm 1.20 \mathrm{mg} / \mathrm{mL})$ had a lower amount of total phenol content.

Table 2 The percentage of moisture, ash, protein, crude fiber, crude fat, carbohydrate and sugar contents and the amount of nutrition values on $P$. macrocarpa fruits

\begin{tabular}{cc}
\hline Test parameter & Percentage of contents \\
\hline Moisture & $13.21 \pm 2.13$ \\
Ash & $5.24 \pm 1.56$ \\
Protein & $8.51 \pm 1.99$ \\
Crude fiber & $38.77 \pm 3.01$ \\
Crude fat & $1.25 \pm 2.65$ \\
Carbohydrate & $33.02 \pm 1.72$ \\
Sugar & $5.57 \pm 1.49$ \\
\hline
\end{tabular}



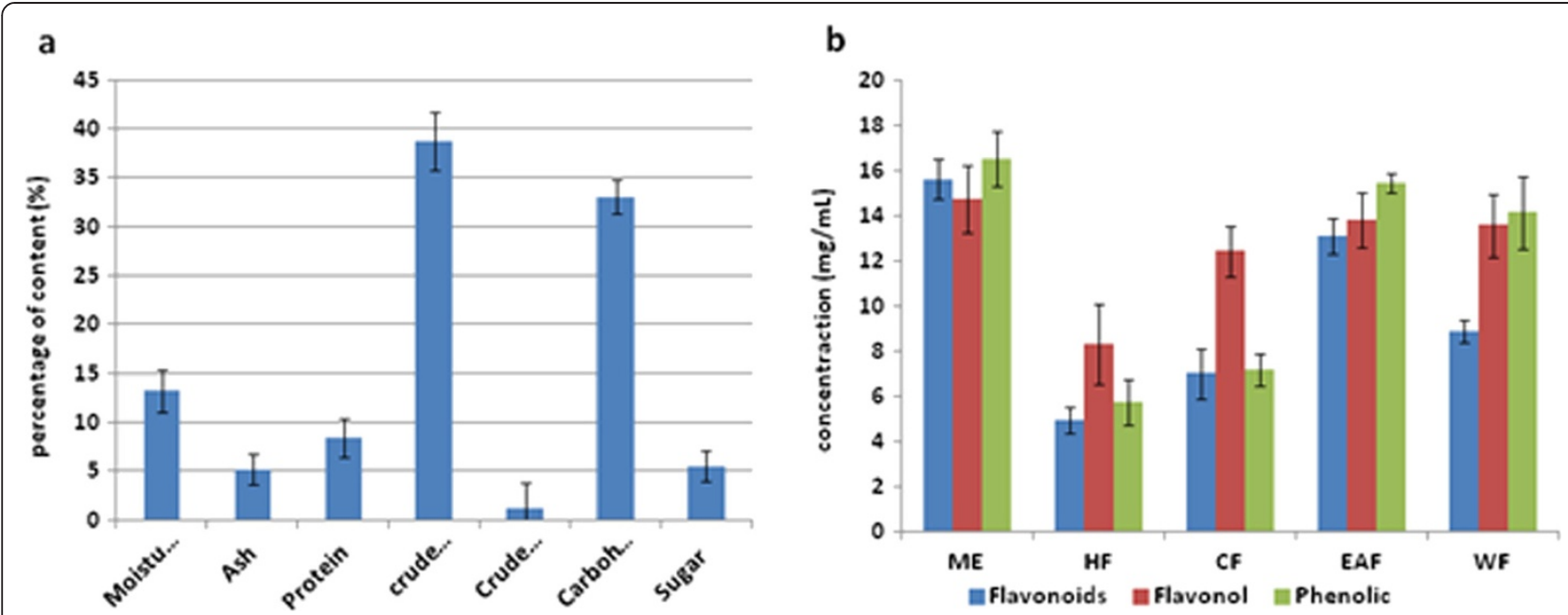

Figure 2 (a) The percentage of moisture, ash, protein, crude fiber, crude fat, carbohydrate and sugar contents on $P$. macrocarpa fruits; (b) Total amount of concentration of flavonoid, flavonol, phenolic contents on methanol extract and its fractions for $P$. macrocarpa fruits. (ME: methanol extract; HF: hexane fraction; CF: chloroform fraction; EAF: ethyl acetate fraction; WF: water fraction).

This data concerning the total amount of flavonoid, flavonol and phenolic content of the methanol extract and its fractions (hexane, chloroform, ethyl acetate and water) of $P$. macrocarpa fruits are shown in Table 4 and Figure 2 (b).

Table 3 Results of preliminary phytochemical consitutents on $P$. macrocarpa fruits

\begin{tabular}{|c|c|c|c|}
\hline No. & Tests & Reagents & Fruit \\
\hline \multirow[t]{4}{*}{1} & Alkaloids & Wagner's Reagent & + \\
\hline & & Mayer's Reagent & + \\
\hline & & Dragendroff's Reagent & + \\
\hline & & Sodium picrate solution & + \\
\hline 2 & a -amino acids & Ninhydrin Reagent & + \\
\hline 3 & Carbohydrates & $10 \%$ a-napthol and conc: $\mathrm{H}_{2} \mathrm{SO}_{4}$ & ++ \\
\hline 4 & Cyanogenic glycosides & Sodium picrate solution & - \\
\hline 5 & Flavonoids & $\mathrm{Mg}$ and conc: $\mathrm{HCl}$ & +++ \\
\hline 6 & Glycosides & $10 \%$ lead acetate & +++ \\
\hline 7 & Organic acids & Bromothymol blue & + \\
\hline 8 & Phenolic compounds & $1 \% \mathrm{FeCl}_{3}$ & +++ \\
\hline \multirow[t]{2}{*}{9} & Reducing sugars & Fehling's solutions & + \\
\hline & & $A$ and $B$ & \\
\hline 10 & Saponin glycosides & Distilled water & +++ \\
\hline 11 & Starch & lodine solution & + \\
\hline 12 & Steroids & Acetic anhydride and conc: $\mathrm{H}_{2} \mathrm{SO}_{4}$ & ++ \\
\hline 13 & Tannins & 1\% Gelatin & +++ \\
\hline 14 & Terpenoids & Acetic anhydride and conc: $\mathrm{H}_{2} \mathrm{SO}_{4}$ & ++ \\
\hline
\end{tabular}

\section{DPPH antioxidant assay}

The ethyl acetate fraction of $P$. macrocarpa exhibited the highest free radical scavenging activity followed by the methanol extract, hexane fraction, chloroform fraction and water fraction. A lower $\mathrm{IC}_{50}$ value corresponds to higher scavenging activity. Scavenging activity was expressed as a percentage of inhibition of DPPH free radicals (Table 4 and Figure 3 ). The antioxidant content was reported as gallic acid equivalents and also $\mathrm{IC}_{50}$ value of the standard gallic acid was $10.8 \pm 0.02 \mathrm{ug} / \mathrm{mL}$ comparable to $\mathrm{IC}_{50}$ values of all extracts. The results of the DPPH assay also showed that the ethyl acetate fraction with an $\mathrm{IC}_{50}$ value of $8.15 \pm 0.02 \mathrm{ug} / \mathrm{mL}$ and methanol extract with an $\mathrm{IC}_{50}$ value of $9.12 \pm 0.03 \mathrm{ug} / \mathrm{mL}$ of $P$. macrocarpa fruit had a stronger scavenging activity than that of the hexane (13.01 \pm 0.2$)$, chloroform $(13.8 \pm 0.03)$ and water $(14.1 \pm 0.03) \mathrm{mg} / \mathrm{mL}$ fractions. It was quite interesting to note that the ethyl acetate fraction and methanol extract recorded high inhibitory activities at all the concentrations tested in an increasing order.

The results of analysis of variance (ANOVA) in five different solutions of flavonoid, flavonol and phenolic contents are shown in Tables 5. The effect(s) of the solutions for different contents at $1 \%$ level showed significant difference.

\section{Cytotoxicity screening on MTT cell proliferation assay}

The methanol extract and its fractions (hexane, chloroform, ethyl acetate, and water) of $P$. macrocarpa fruits were investigated for their cytotoxic effects in Ca Ski, MCF-7, HT-29, SKOV-3, MDA-MB231 and normal fibroblast lung cells (MRC-5) and normal liver cells (WRL-68) using MTT cell proliferation assay at 24 hours, 48 hours and 72 hours respectively. 
Table 4 Total flavonoid, total flavonol, total phenolic contents and result of DPPH free radical scavenging property of P. macrocarpa fruits

\begin{tabular}{cccccc}
\hline Test parameter & $\mathbf{M E}(\mathbf{m g} / \mathbf{m l})$ & $\mathbf{H F}(\mathbf{m g} / \mathbf{m l})$ & $\mathbf{C F}(\mathbf{m g} / \mathbf{m l})$ & $\mathrm{EAF}(\mathbf{m g} / \mathbf{m l})$ & $\mathbf{W F}(\mathbf{m g} / \mathbf{m l})$ \\
\hline Flavonoid & $15.62^{\mathrm{a}} \pm 0.9$ & $4.98^{\mathrm{b} c} \pm 0.6$ & $7.04^{\mathrm{b}} \pm 1.1$ & $13.11^{\mathrm{a}} \pm 0.8$ & $13.91^{\mathrm{b}} \pm 0.5$ \\
Flavonol & $14.75^{\mathrm{a}} \pm 1.5$ & $8.32^{\mathrm{c}} \pm 1.8$ & $12.46^{\mathrm{b}} \pm 1.1$ & $134^{\mathrm{a}} \pm 1.2$ & $13.6^{\mathrm{a}} \pm 1.6$ \\
Phenolic & $16.54^{\mathrm{a}} \pm 1.5$ & $5.75^{\mathrm{c}} \pm 1.2$ & $7.20^{\mathrm{c}} \pm 0.7$ & $15.46^{\mathrm{a}} \pm 0.4$ & $14.15^{\mathrm{ab}} \pm 1.9$ \\
DPPH & $9.12^{\mathrm{b}} \pm 0.03$ & $13.01^{\mathrm{a}} \pm 0.2$ & $13.8^{\mathrm{a}} \pm 0.03$ & $8.15^{\mathrm{b}} \pm 0.02$ & $14.1^{\mathrm{a}} \pm 0.03$ \\
\hline
\end{tabular}

(ME: Methanol Extract; HF: Hexane Fraction; CF: Chloroform Fraction; EAF: Ethyl Acetate Fractions; WF: Water Fraction); The means of the each parameters extracts with same small letters were not significantly different as per Duncan's multi-range test at $\mathrm{P}<0.05$.

The methanol extract of $P$. macrocarpa fruits showed good cytotoxicity with an $\mathrm{IC}_{50}$ value of $20.3 \pm 3.71 \mu \mathrm{g} / \mathrm{mL}$ at $24 \mathrm{hrs}$ against a breast cancer cell line (MDA-MB231). The $\mathrm{IC}_{50}$ values for the methanol extract measured at $48 \mathrm{hrs}$ and $72 \mathrm{hrs}$ of treatment in MDA-MB231 were $34.6 \pm 1.83$ and $95 \pm 2.11 \mu \mathrm{g} / \mathrm{mL}$. The methanol extract showed the highest inhibitory effect against ovarian cancer cells (SKOV-3) at $72 \mathrm{hrs}\left(\mathrm{IC}_{50}\right.$ value $\left.7.75 \pm 2.56 \mu \mathrm{g} / \mathrm{mL}\right)$. However, at $24 \mathrm{hrs}$ and $48 \mathrm{hrs}$ of exposure to the methanol extract, $\mathrm{IC}_{50}$ values were less impressive $(80.0 \pm 2.44$ and $68.1 \pm 1.81 \mu \mathrm{g} / \mathrm{mL}$ respectively). The methanol extract displayed moderate cytotoxic activity in HT-29 cells with an $\mathrm{IC}_{50}$ value of $38.5 \pm 1.82 \mu \mathrm{g} / \mathrm{mL}$ at $72 \mathrm{hrs}$ and very low cytotoxic effect with $\mathrm{IC}_{50}$ values of $83.5 \pm 2.52$ and $68.1 \pm 1.81 \mu \mathrm{g} / \mathrm{mL}$ at $24 \mathrm{hrs}$ and $48 \mathrm{hrs}$ respectively. However, the methanol extract did not exhibit any cytotoxic effect against $\mathrm{Ca}$ Ski, and MCF-7 cells with $\mathrm{IC}_{50}>100$ $\mu \mathrm{g} / \mathrm{mL}$. In addition, the extract also did not show any cytotoxic effect on normal MRC-5 cells and WRL-68 cells with $\mathrm{IC}_{50}>100 \mu \mathrm{g} / \mathrm{mL}$. Therefore, it can be concluded that the methanol extract exhibited high cytotoxicity in SKOV-3 at $72 \mathrm{hrs}$ and MDA-MB231 at 24 hrs, moderate cytotoxicity at $48 \mathrm{hrs}$ in MDA-MB-231 and HT-29 at $72 \mathrm{hrs}$, very low cytotoxicity in HT-29 at 24 hrs and 48 hrs and SKOV-3 at 24 hrs and 48 hrs, and no cyctotoxicity in MCF-7, Ca Ski and MRC-5 cells.

The hexane fraction of $P$. macrocarpa fruits showed good cytotoxic effect with an $\mathrm{IC}_{50}$ value of $10.15 \pm 2.71 \mu \mathrm{g} / \mathrm{mL}$ at $24 \mathrm{hrs}$ in SKOV-3, $5.8 \pm 2.15$ and $4.6 \pm 1.32 \mu \mathrm{g} / \mathrm{mL}$ at $24 \mathrm{hrs}$ and $48 \mathrm{hrs}$ in MDA-MB 231. The $\mathrm{IC}_{50}$ value for the treatment of MDA-MB 231 with the hexane fraction was $34.3 \pm 2.19 \mu \mathrm{g} / \mathrm{mL}$ at $72 \mathrm{hrs}$ and the $\mathrm{IC}_{50}$ value of treatment in SKOV-3 were 69.0 $2.56,72.5 \pm 3.13 \mu \mathrm{g} / \mathrm{mL}$ at $24 \mathrm{hrs}$ and $48 \mathrm{hrs}$. Additionally, this hexane fraction displayed moderate cytotoxic effect on HT-29 cells with an $\mathrm{IC}_{50}$ value of $81.5 \pm 3.0,60.0 \pm 2.33$ and $68.1 \pm 3.75 \mu \mathrm{g} / \mathrm{mL}$ at $24 \mathrm{hrs}, 48 \mathrm{hrs}$ and 72 hours. Furthermore, there was no cytotoxic effect in Ca Ski or MCF-7 cells except for an $\mathrm{IC}_{50}$ value of $44.1 \pm 2.38 \mu \mathrm{g} / \mathrm{mL}$ at $48 \mathrm{hrs}$ in MCF-7. The hexane fraction displayed high cytotoxic effect in

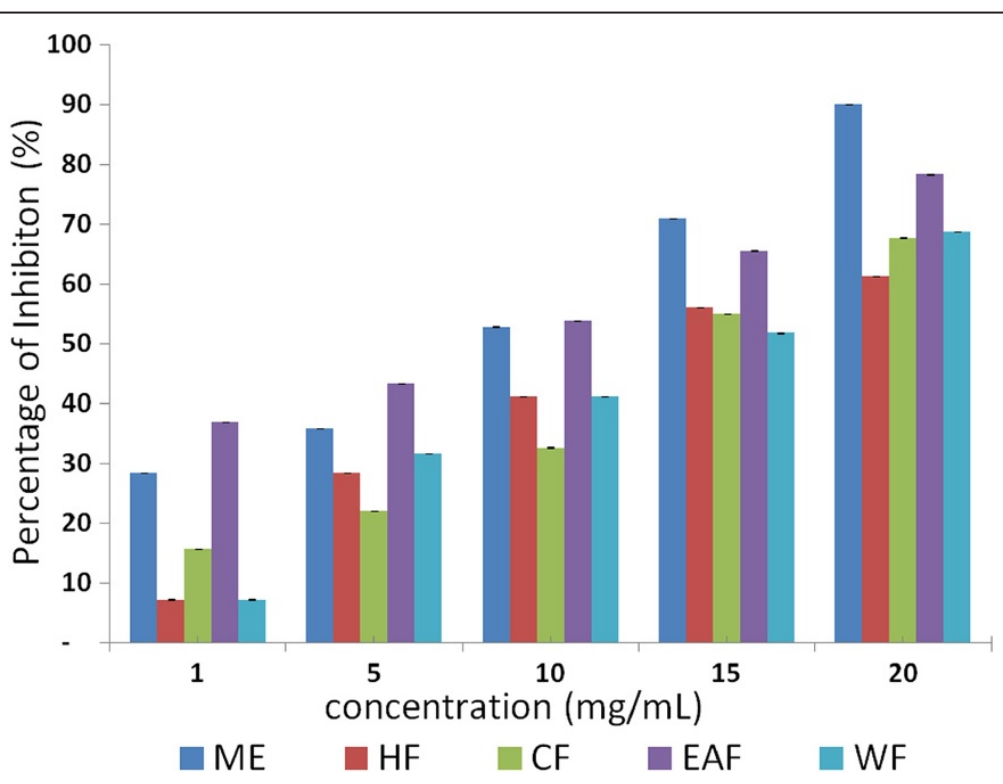

Figure 3 Percentage of inhibition of DPPH free radical scavenging by the methanol extract and its fractions for $P$. macrocarpa fruits. (ME: methanol extract; HF: hexane fraction; CF: chloroform fraction; EAF: ethyl acetate fraction; WF: water fraction). 
Table 5 ANOVA of different contents at various solutions

\begin{tabular}{cccccc}
\hline S.O.v & df & Phenolic & Flavonol & Flavonoid & DPPH \\
\hline Solution & 4 & $0.0141^{* *}$ & $0.0168^{* *}$ & $0.4322^{* *}$ & $0.00032^{* *}$ \\
Replication & 2 & $1.3 \mathrm{E}-06$ & $1.70 \mathrm{E}-07$ & $1.00 \mathrm{E}-05$ & $2 \mathrm{E}-07$ \\
Error & 8 & $3.5 \mathrm{E}-06$ & $2.20 \mathrm{E}-07$ & $1.00 \mathrm{E}-06$ & $3.00 \mathrm{E}-06$ \\
CV\% & & 16 & 13 & 19 & 12 \\
\hline
\end{tabular}

**: Correlation coefficients between conditions were significant at $1 \%$ probability level.

SKOV-3 at $24 \mathrm{hrs}$ and MDA-MB231 at $24 \mathrm{hrs,} \mathrm{moder-}$ ate cytotoxic effect at $48 \mathrm{hrs}$ in MDA-MB231 at $48 \mathrm{hrs}$ and HT-29 at 72 hrs, very low cytotoxic effect in HT-29 at $24 \mathrm{hrs}$ and $48 \mathrm{hrs}$, SKOV- 3 at $24 \mathrm{hrs}$ and $48 \mathrm{hrs}$, and no cyctotoxic effect in MCF-7, Ca Ski, MRC-5 and WRL-68. The hexane fraction also exhibited high cytotoxic effect in SKOV-3 at $72 \mathrm{hrs}$ and MDA-MB231 at $24 \mathrm{hrs}$ and $48 \mathrm{hrs,}$ moderate cytotoxic effect in MDA-MB231 at $48 \mathrm{hrs}$ and MCF-7 at 48 hrs, low cytotoxic effect in SKOV-3 at 48 hrs and 72 hrs, HT-29 at 24 hrs, 48 hrs and 72 hrs, and no cytotoxic effect in Ca Ski at $24 \mathrm{hrs}, 48 \mathrm{hrs}$ and $72 \mathrm{hrs}$, as well as in MCF-7 at 24 hrs and 72 hrs.

The chloroform fraction of $P$. macrocarpa fruits exhibited the highest cytotoxic effect with an $\mathrm{IC}_{50}$ value of $14.6 \pm 1.45,7.8 \pm 1.57$ and $15.3 \pm 1.72 \mu \mathrm{g} / \mathrm{mL}$ after $24 \mathrm{hrs}$, $48 \mathrm{hrs}$ and $72 \mathrm{hrs}$ of incubation in MDA-MB 231. The chloroform fraction showed moderate cytotoxic effect with $\mathrm{IC}_{50}$ values of $41.2 \pm 3.66,44.0 \pm 3.76,37.0 \pm 2.65 \mu \mathrm{g} / \mathrm{mL}$ at $24 \mathrm{hrs}, 48 \mathrm{hrs}$ and $72 \mathrm{hrs}$ against HT-29 cells. The chloroform fraction also exhibited moderate cytotoxic effect in SKOV-3 with $\mathrm{IC}_{50}$ values of $35.0 \pm 1.11,37.5 \pm 1.62$, $37.0 \pm 2.65 \mu \mathrm{g} / \mathrm{mL}$ at $24 \mathrm{hrs}, 48 \mathrm{hrs}$ and $72 \mathrm{hrs}$. Low cytotoxic activity was observed in $\mathrm{SKOV}-3$ with an $\mathrm{IC}_{50}$ value of $80.0 \pm 4.56$ at 72 hrs. In MCF-7 cells, this choloroform fraction displayed cytotoxic effect with an $\mathrm{IC}_{50}$ value of $36.3 \pm 2.76 \mu \mathrm{g} / \mathrm{mL}$ at $24 \mathrm{hrs}$ but low cytotoxic effect with an $\mathrm{IC}_{50}$ value of $85.5 \pm 1.76 \mu \mathrm{g} / \mathrm{mL}$ at $48 \mathrm{hrs}$ with no cytotoxic effect at $72 \mathrm{hrs}\left(\mathrm{IC}_{50}>100 \mu \mathrm{g} / \mathrm{mL}\right)$. In contrast, the chloroform fraction did not display any cytotoxic effect against Ca Ski cells and normal MRC-5 and WRL-68 cells $\left(\mathrm{IC}_{50}>100 \mu \mathrm{g} / \mathrm{mL}\right)$. In conclusion, the chloroform fraction exhibited highest cytotoxic effect in MDA-MB 231 cells at $24 \mathrm{hrs}, 48 \mathrm{hrs}$ and $72 \mathrm{hrs}$, moderate cytotoxic effect in MCF-7 cells at 24 hrs, HT- 29 cells for $24 \mathrm{hrs}, 48 \mathrm{hrs}$ and $72 \mathrm{hrs}$, and SKOV- 3 cells at 24 hrs and 48 hrs, low cytotoxic effect in MCF-7 at 48 hrs and SKOV-3 cells at $72 \mathrm{hrs}$, and no cytotoxic effect in Ca Ski at $24 \mathrm{hrs}, 48 \mathrm{hrs}$ and $72 \mathrm{hrs}$, and also MCF-7 at $72 \mathrm{hrs}$.

The ethyl acetate fraction of $P$. macrocarpa fruits showed good cytotoxic effect with $\mathrm{IC}_{50}$ values of $21.85 \pm 2.58$, $8.1 \pm 1.81 \mu \mathrm{g} / \mathrm{mL}$ at $48 \mathrm{hrs}$ and $72 \mathrm{hrs}$ in SKOV-3 cells, $6.8 \pm 2.08,6.4 \pm 1.09,16.2 \pm 2.4 \mu \mathrm{g} / \mathrm{mL}$ at $24 \mathrm{hrs}, 48 \mathrm{hrs}$ and $72 \mathrm{hrs}$ in MDA-MB 231 cells, $16.5 \pm 2.45,23.00 \pm 3.44 \mu \mathrm{g} / \mathrm{mL}$ at $24 \mathrm{hrs}$ and $48 \mathrm{hrs}$ in MCF-7 cells. In addition, this ethyl acetate fraction displayed moderate cytotoxic effect in MCF-7 with $\mathrm{IC}_{50}$ values of $43.5 \pm 4.03 \mu \mathrm{g} / \mathrm{mL}$ at $72 \mathrm{hrs}$, and $46.0 \pm 1.14 \mu \mathrm{g} / \mathrm{mL}$ at $24 \mathrm{hrs}$ in SKOV-3. It exhibited low cytotoxicity in HT-29 cells with an $\mathrm{IC}_{50}$ value of $83.5 \pm 2.52 \mu \mathrm{g} / \mathrm{mL}$ at $72 \mathrm{hrs}$. On the other hand, this ethyl acetate fraction was not cytotoxic towards Ca Ski cells, WRL-68 and MRC-5 normal cells. These results are shown in Table 6 and Figure 4.

Results of combined analysis of five different concentrations, three time points, five cell lines and interaction among them showed that effect of cytotoxic at probability at $1 \%$ level were significantly different (Table 7 ).

The water extract showed no cytotoxic effect in all investigated cancer cell lines and normal MRC- 5 cells $\left(\mathrm{IC}_{50}>100 \mu \mathrm{g} / \mathrm{mL}\right)$.

\section{Discussion}

The major nutritional components such as moisture, ash, lipids, proteins, fibres, carbohydrates, and total sugar were found to be in the suitable range along with good energy. In our present study, the crude fibre of $P$. macrocarpa fruits were of a higher percentage compared to its ash, carbohydrate, sugar, proteins and fat contents. The quality and nutritional value of the fruits have a direct relationship with their crude protein content and inverse relationship with its crude fibre content. At the beginning of the growing season, P. macrocarpa fruits have the least nutritional value and quality. The quality improves upon maturity. The amount of carbohydrates increases with the completion of the fruit growing stages, while the density of fibre is decreased.

The crude fibre in fruits and vegetables usually consists of cellulose, hemicellulose, lignin, $\beta$-glucans, gums and pectin [30]. The high crude fibre content suggested the fruits may be a good source for phenolic antioxidants. This was confirmed by our results.

Many flavonoids and terpenoids are potent antioxidants, anti-inflammatory, anti-bacterial, anti-viral and anti-cancer agents [31]. Phenolics have anti-oxidative, anti-diabetic, anti-carcinogenic, anti-microbial, anti-allergic, anti-inflammtory, anti-mutagenic activities [32,33]. Steroids are known to be important for their cardiotonic activities and possess insecticidal and anti-microbial properties while tannins are known to possess general antimicrobial and antioxidant activities [34]. Saponins are used in treatment of hypercholesterolemia, hyperglycemia, as antioxidants, anticancers, anti-fungal, anti-bacterial, anti-inflammatory and in weight loss $[32,35]$. Based on preliminary phytochemical studies, the results revealed that the chemical components of $P$. macrocarpa fruit also contained large amounts of flavonoids, phenolics, steroids, tannins, terpenoids, glucosides, and saponins. It also contained small amounts of amino acids, carbohydrates, starch, reducing 
Table 6 In vitro, cytotoxic effects of methanol extract and its fractions of $P$. macrocarpa fruits on Ca Ski, MCF-7, HT-29, SKOV3 and MDA-MB231 cancer cells lines

\begin{tabular}{|c|c|c|c|c|c|c|}
\hline Extract & & ME & HF & $\mathrm{CF}$ & EAF & WF \\
\hline \multirow[t]{2}{*}{ Cell line } & $\mathrm{hr}$ & & & & & \\
\hline & 24 & $\geq 100^{\mathrm{a}}$ & $\geq 100^{\mathrm{a}}$ & $\geq 100^{\mathrm{a}}$ & $\geq 100^{\mathrm{a}}$ & $\geq 100^{\mathrm{a}}$ \\
\hline \multirow[t]{3}{*}{ Ca Ski } & 48 & $\geq 100^{\mathrm{a}}$ & $\geq 100^{\mathrm{a}}$ & $\geq 100^{\mathrm{a}}$ & $\geq 100^{\mathrm{a}}$ & $\geq 100^{\mathrm{a}}$ \\
\hline & 72 & $\geq 100^{\mathrm{a}}$ & $\geq 100^{\mathrm{a}}$ & $\geq 100^{a}$ & $\geq 100^{\mathrm{a}}$ & $\geq 100^{\mathrm{a}}$ \\
\hline & 24 & $\geq 100^{a}$ & $\geq 100^{\mathrm{a}}$ & $36.3^{c} \pm 2.76$ & $16.5^{c} \pm 2.45$ & $\geq 100^{\mathrm{a}}$ \\
\hline \multirow[t]{3}{*}{ MCF-7 } & 48 & $\geq 100^{\mathrm{a}}$ & $44.1^{b} \pm 2.38$ & $85.5^{b} \pm 1.76$ & $23.0^{\mathrm{b}} \pm 3.44$ & $\geq 100^{\mathrm{a}}$ \\
\hline & 72 & $\geq 100^{\mathrm{a}}$ & $\geq 100^{\mathrm{a}}$ & $\geq 100^{\mathrm{a}}$ & $43.5^{\mathrm{a}} \pm 4.03$ & $\geq 100^{\mathrm{a}}$ \\
\hline & 24 & $96^{\mathrm{a}} \pm 2.92$ & $81.5^{\mathrm{a}} \pm 3.0$ & $41.2^{\mathrm{a}} \pm 3.66$ & $32.1^{b c} \pm 2.32$ & $\geq 100^{\mathrm{a}}$ \\
\hline \multirow[t]{3}{*}{ HT-29 } & 48 & $83.5^{\mathrm{ab}} \pm 2.52$ & $60.0^{b} \pm 2.33$ & $44.0^{\mathrm{a}} \pm 3.76$ & $44.5^{b} \pm 1.29$ & $\geq 100^{\mathrm{a}}$ \\
\hline & 72 & $38.5^{\mathrm{b}} \pm 1.82$ & $68.1^{b} \pm 3.75$ & $37.0^{\mathrm{ab}} \pm 2.65$ & $83.5^{\mathrm{a}} \pm 2.52$ & $\geq 100^{\mathrm{a}}$ \\
\hline & 24 & $80.0^{\mathrm{a}} \pm 2.44$ & $10.15^{\mathrm{b}} \pm 2.71$ & $35.0^{b} \pm 1.11$ & $46.0^{\mathrm{a}} \pm 1.14$ & $\geq 100^{\mathrm{a}}$ \\
\hline \multirow[t]{3}{*}{ SKOV-3 } & 48 & $68.1^{\mathrm{ab}} \pm 1.81$ & $69.0^{\mathrm{a}} \pm 2.56$ & $37.5^{b} \pm 1.62$ & $21.85^{\mathrm{b}} \pm 2.58$ & $\geq 100^{\mathrm{a}}$ \\
\hline & 72 & $7.75^{\complement} \pm 2.56$ & $72.5^{\mathrm{a}} \pm 3.13$ & $80.0^{\mathrm{a}} \pm 4.56$ & $8.1^{\mathrm{c}} \pm 1.81$ & $\geq 100^{\mathrm{a}}$ \\
\hline & 24 & $20.3^{b} \pm 3.71$ & $5.8^{\mathrm{b}} \pm 2.15$ & $14.6^{\mathrm{a}} \pm 1.45$ & $6.8^{\mathrm{b}} \pm 2.08$ & $\geq 100^{\mathrm{a}}$ \\
\hline \multirow[t]{2}{*}{ MDA-MB231 } & 48 & $34.6^{\mathrm{b}} \pm 1.83$ & $4.6^{\mathrm{b}} \pm 1.32$ & $7.8^{b} \pm 1.57$ & $6.4^{\mathrm{b}} \pm 1.09$ & $\geq 100^{\mathrm{a}}$ \\
\hline & 72 & $95^{\mathrm{a}} \pm 2.11$ & $34.3^{\mathrm{a}} \pm 2.19$ & $15.3^{\mathrm{a}} \pm 1.72$ & $16.2^{\mathrm{a}} \pm 2.4$ & $\geq 100^{\mathrm{a}}$ \\
\hline
\end{tabular}

(ME: Methanol Extract; HF: Hexane Fraction; CF: Chloroform Fraction; EAF: Ethyl Acetate Fractions; WF: Water Fraction); The means of the extracts with same small letters were not significantly different as per Duncan's multi-range test at $P<0.05$.

sugars, alkaloids and steroids. The ethyl acetate extract from the P. macrocarpa fruit flesh contained flavonoids, triterpenoids and coumarin groups [2]. The essential oil from $P$. macrocarpa fruit flesh are known to contain octadecane, triclosan, octacosane, diethylester and tributyl citrate [36].

Flavonoids and flavonols have an essential role in drugs particularly those involved in the reduction of cholesterol and fat and in the reduction of the risk of coronary heart disease. Rohyami [37] reported that the methanol extract of $P$. macrocarpa dried fruits was high in total flavonoids. In our investigation, the total flavonoid and flavonol contents of $P$. macrocarpa fruits were highest in the methanol extract, followed by ethyl acetate, water, chloroform, and hexane fractions.

According to previous researches, phenolics have many biological activities such as an antioxidant, antimutagenic, anticarcinogenic, anti-inflammatory and antimicrobial activities. Hendra suggested that the antioxidant activity of the fruits of $P$. macrocarpa was due to the presence of phenolic and flavonoid compounds, the majority of which are kaempferol, myricetin, naringin, quercetin and rutin [5]. Our results showed that phenolic compounds were present at the highest percentage in the methanol extract, followed by ethyl acetate, water, chloroform and hexane fractions.

Rudi [5,9] reported that $P$. macrocarapa fruits have good antioxidant activity due to the presence of flavonoid and phenolic contents. The compound 6, 4'-dihydroxy-4methoxy benzophenone-2-0- $\alpha$-D-glucoside isolated from the butanol extract of P. macrocarpa fruits was shown to possess good antioxidant activity [38]. Our results showed that the ethyl acetate fraction and methanol extract of $P$. macrocarpa fruits possessed the highest radical scavenging activity, followed by hexane, chloroform, and water fractions. This is consistent with the high phenolic content of the ethyl acetate fraction as phenolics are known to have good antioxidant activity.

It has been shown that $P$. macrocarpa fruits displayed cytotoxic effect on HT-29, MCF-7 and Hela cell lines [5]. Faried [39] have isolated gallic acid from the fruits of P. macrocarpa and demonstrated that it could cause cancer cell death in various cancer cells, including the human esophageal cancer (TE-2), gastric cancer (MKN-28), colon cancer (HT-29), breast cancer (MCF-7), cervix cancer (Ca Ski), and malignant brain tumor (CGNH-89 and CGNH-PM). In our study, various cell lines were treated with different concentrations of different sample for $24 \mathrm{hrs}, 48 \mathrm{hrs}$ and $72 \mathrm{hrs}$. The methanol extract, hexane, chloroform, ethyl acetate, and water fractions were found to inhibit MCF-7, SKOV-3, HT-29, and MDA-MB 231 cell proliferation in a time- and dose-dependent manner. However, all extracts and fractions did not exert any cytotoxic effect on Ca Ski cervical cancer cell line, normal human fibroblast lung cells (MRC5) or normal human liver cells (WRL 68).

Taken together, our results showed that the fruits of the P. macrocarpa plant have a high content of secondary metabolites including flavonoids, flavonols and phenolics, and good nutritional value which contribute to 


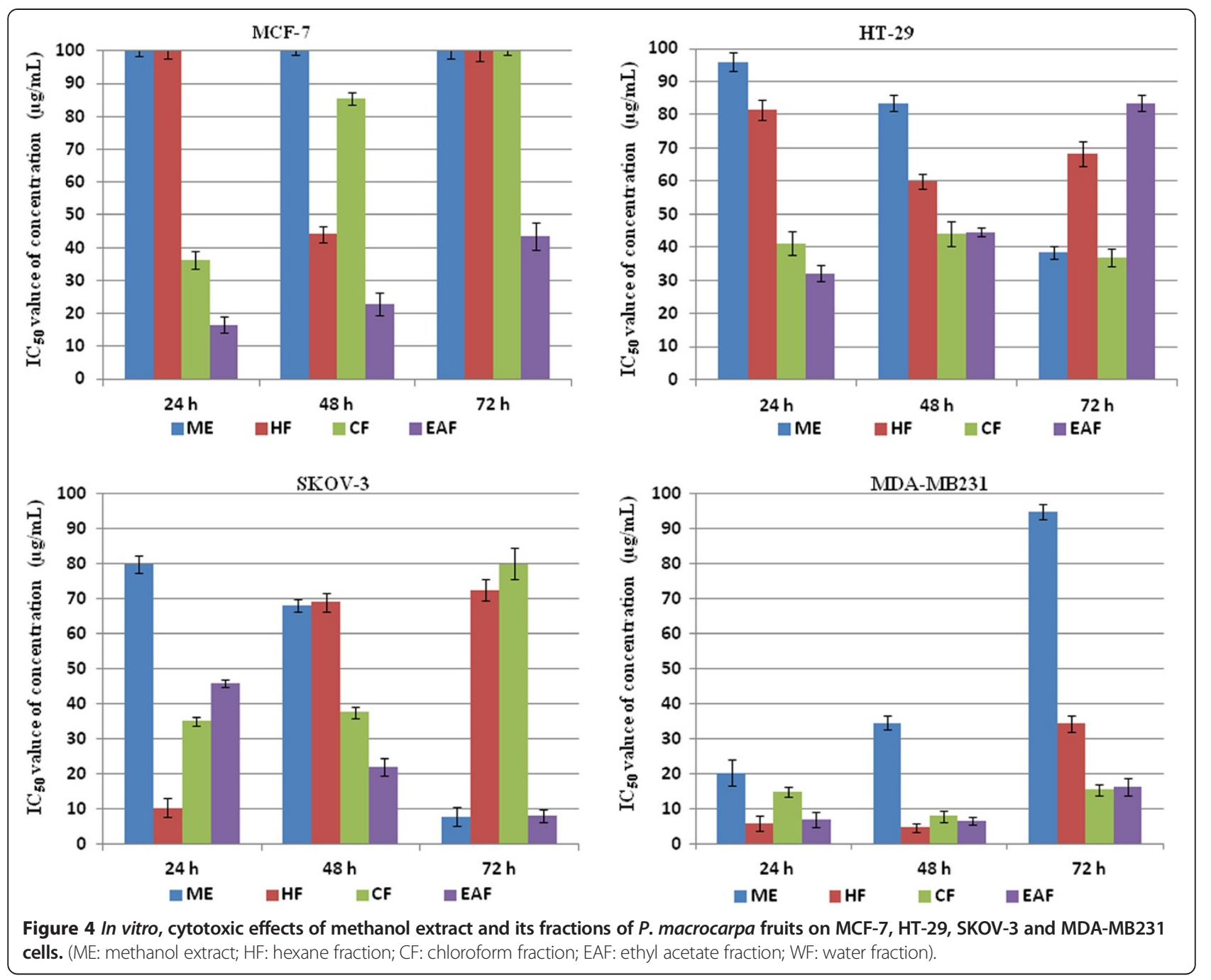

Figure 4 In vitro, cytotoxic effects of methanol extract and its fractions of $P$. macrocarpa fruits on MCF-7, HT-29, SKOV-3 and MDA-MB231 cells. (ME: methanol extract; HF: hexane fraction; CF: chloroform fraction; EAF: ethyl acetate fraction; WF: water fraction).

Table 7 Summary of combined analysis and the level of significant mean squares for five cell lines, three hours and five solutions populations of $P$. macrocarpa fruits

\begin{tabular}{lcccc}
\hline S.O.v & df & Seq SS & Adj MS & F \\
\hline Cell line (Cell) & 4 & 65420.2 & 16355 & $* *$ \\
Hour (Hr) & 2 & 1572.8 & 786.4 & $* *$ \\
Solution & 4 & 55766.5 & 13941.6 & $* *$ \\
Cell ${ }^{*} H r$ & 8 & 4196.9 & 524.6 & $* *$ \\
Cell ${ }^{*}$ solution & 16 & 30845.3 & 1927.8 & $* *$ \\
Hr* $^{*}$ solution & 8 & 4193.3 & 524.2 & $* *$ \\
Cell*Hr*Solution & 32 & 29067 & 908.3 & $* *$ \\
Error & 74 & $8.80 \mathrm{E}-05$ & $1.20 \mathrm{E}-06$ & \\
\hline
\end{tabular}

**: Correlation coefficients between conditions were significant at $1 \%$ probability level. the excellent antioxidant, anti-inflammatory and cytotoxic activities.

\section{Conclusion}

In this study, the antioxidant and cytotoxic activities of P. macrocarpan fruits on selected cell lines were investigated. In addition, the total preliminary phytochemical constituents such as flavonoids, flavonols, phenolic contents and nutritional values were determined. The results showed that the fruit has a high nutritional value, with good antioxidant and cytotoxic activities. The methanol extract * of the fruit merits further investigation as it exhibited a ** host of beneficial qualities. It has the potential to yield compounds that may be developed into chemotherapeutic agents.

\section{** Abbreviations}

(EAF): Ethyl acetate fraction; (ME): Methanol extract; (HF): Hexane fraction; (CF): Chloroform fraction; (WF): Water fraction; (MTT): 3, 4, 5-dimethylthiazol-2yl)-2-5-diphenyltetrazolium bromide; (DPPH): 1, 1 Diphenyl -1- picrylhydrazyl; (g): Gram; (\%): Percentage. 


\section{Competing interests}

The authors declare that they have no competing interests.

\section{Authors' contributions}

MML was involved in all experiments and SM was involved statistical analysis. All authors read and approved the submitted version of the manuscript.

\section{Acknowledgements}

The work was supported by grants from Malaysia Ministry of Higher Education (No. PS286/2009C and PS470/2010B). Ma Ma Lay is a scholarship recipient from the "Islamic Development Bank, Saudi Arabia". We would like to thank Professor Dr. Amru Bin Nasrulhaq Boyce for the use of his laboratory.

\section{Author details}

${ }^{1}$ Institute of Biological Sciences, Faculty of Science, University of Malaya, 50603 Kuala Lumpur, Malaysia. ${ }^{2}$ Univerisity of Malaya Centre for Proteomics Research (UMCPR), University of Malaya, 50603 Kuala Lumpur, Malaysia.

Received: 17 June 2013 Accepted: 17 April 2014

Published: 8 May 2014

\section{References}

1. Susanthy E: N-Hexane Extract Cytotoxicity Beans and Meat Mahkota Dewa Fruit (Phaleria Macrocarpa [Scheff.] Boerl.) Against HeLa and Myeloma Cell Line. Yogyakarta: Skripsi FMIPA UGM; 2005:47-50.

2. Hartati W, Mae S, Mubarika S, Gandjar Gl, Hamann TM, Rao K: Phalerin, a new benzophenoic glucoside isolated from the methanolic extract of Mahkota Dewa [ Phaleria macrocarpa (Scheff.) Boerl. ] Leaves. Majalah Farmasi Indones 2005, 16(1):51-57.

3. Jemal A, Siegel R, Ward E: Cancer statistics. CA Cancer J Clin 2007, 57(1):46-66

4. Harmanto N: Mahkota Dewa Obat Pusaka Para Dewa. Jakarta: Cetakan keempat,Agromedia Pustaka; 2002:4-11.

5. Rudi H, Syahida A, Aspollah S, Yunus Shukor M, Ehsan O: Flavonoid analyses and antimicrobial activity of various parts of Phaleria macrocarpa (Scheff.) Boerl fruit. Int J Mol Sci 2011, 12:3422-3431.

6. Triastuti A, Choi JW: Protective effects of ethyl acetate fraction of Phaleria macrocarpa (Scheff) Boerl. on oxidative stress asssociated with alloxan-induced diabetic rats. J Ilmiah Farmasi 2008, 5(1):9-17.

7. Sugiwati S, Setiasih S, Afifah E: Antihypergl ycemic activity of the mahkota dewa leaf. extracts as an alpha-glucosidase inhibitor. J Logika 2009, 13(2):74-78.

8. Triastuti A, Park E-J, Choi JW: Phaleria macrocarpa suppress nephropathy by increasing renal antioxidant enzyme activity in alloxan-induced diabetic rats. Nat Prod Sci 2009, 15(3):167-172.

9. Rudi H, Ahmad S, Oskoueian E, Sukari A, Shukor MY: Antioxidant, anti-inflammatory and cytotoxicity of Phaleria macrocarpa (Boerl.) Scheff fruit. BMC Complement Altern Med 2011, 11(1):110.

10. Evans WC: Trease and Evans Pharmacognosy. 15th edition. Saunder: Saunder; 2002:528-541.

11. Harborne J: Phytochemical Methods. London: Chapman and Hall Ltd; 1973.

12. AOAC: Official Methods of Analysis. 17th edition. Gaithersburg, MD,USA: Gaithersburg, MD,USA; 2000.

13. AOAC: Official Methods of Analysis. Arlington: Association of Official Analytical Chemists; 2002.

14. Alekhya C, Yasodamma N, Chaithra D, Job Roger Binny A: Anthelmintic activity of aeschynomene aspera and aeschynomene indica. Int J Pharm Pharm Sci 2013, 5(2):386-388.

15. Horwitz W: Official Method of Analysis. 17th edition. Maryland, USA: AOAC Interantional; 2000

16. Adedapo A, Jimoh F, Koduru S, Masika J, Afolayan A: Assessment of the medicinal potentials of the methanol extracts of the leaves and stems of Buddleja saligna. BMC Complement Altern Med 2009, 9:9-21.

17. Koncić M, Kremer D, Gruz J, Strnad M, Bisevac G, Kosalec I: Antioxidant and antimicrobial properties of Moltkia petraea (tratt.) Griseb. flower, leaf and stem infusions. Food Chem Toxicol 2001, 48(6):1537-1542.

18. McDonald S, Prenzler PD, Autolovich M, Robards K: Phenolic content and antioxidant activity of olive oil extracts. Food Chem Biol Interact 2001, 73:73-84.

19. Nabavi S, Ebrahimzadeh M, Nabavi S, Hamidinia A, Bekhradnia A: Determination of antioxidant activity, phenol and flavonoids content of Parrotia persica Mey. Pharmacol Online 2008, 2:560-567.
20. Tarunpreet ST, Rajbir S, Rajbir K, Geetanjali R, Saroj A: In vitro antiradical properties and total phenolic contents in methanol extract/fractions from bark of Schleichera oleosa (Lour.) Oken. Med Chem Res 2011, 20(2):254-260.

21. Ebrahimzadeh M, Nabavi S, Nabavi S: Antioxidant activities of methanol extract of sambucus ebulus L. flower. Pak J Biol Sci 2001, 12:447-450.

22. Ordonez A, Gomez J, Vattuone M, Isla M: Antioxidant activities of Sechium edule (Jacq). Food Chem 2006, 97:452-458.

23. Kumaran A, Karunakaran R, 344-352. ST: In vitro antioxidant activities of methanol extracts of five Phyllantus species from India. Food Sci Technol 2007, 40:344-352.

24. Mbaebie B, Edeoga H, Afolayan A: Phytochemical analysis and antioxidants activities of aqueous stem bark extract of Schotia latifolia Jacq. Asian Pac J Trop Biomed 2012, 2(2):118-124.

25. Mensor LI, Menezes FS, Leitao GG, Reis AS, dos Santos T, Coube CS, Leitao SG: Screening of Brazilian plants extracts for antioxidants activity by the use of DPPH free radical method. Phytother Res 2001, 15:127-130.

26. Yanping $H$, Shunquan $L$, Yueming J, Muhammad A: Variation in contents of total phenolics and flavonoids and antioxidant activities in the leaves of 11 eriobotrya species. Plant Foods Hum Nutr 2008, 63(4):200.

27. Denizot F, Lang R: Rapid colorimetric assay for cell growth and survival, modifications to the tetrazolium dye procedure giving improved sensitivity and reliability. J Immunol Methods 1986, 89:271-277.

28. Mosmann T: Rapid colorimetric assay for cellular growth and survival: application to proliferation and cytotoxicity assays. $J$ Immunol Methods 1983, 65:55-63.

29. Jitender M, Chetan SC, Manu S: Human epithelial carcinoma cytotoxicity and inhibition of DMBA/TPA induced squamous cell carcinoma in Balb/c mice by Acacia catechu heartwood. J Pharm Pharmacol 2011, 63(11):1470-1482.

30. Sayago-Ayerdi SG, Arranz S, Serrano J, Goni I: Dietary fiber content and associated antioxidant compounds in roselle flower (Hibiscus sabdariffa L.) beverage. J Agric Food Chem 2007, 55(19):7886-7890.

31. Oliver Chen C, Blumberg J: Are there age-related changes in flavonoid bioavailability? Phytochemicals aging and health. New York: Taylor Francis Group; 2008.

32. Manjunatha B: Antibacterial activity of Pterocarpus santalinus. Indian J Pharm Sci 2006, 68(1):115-116.

33. Arts I, Hollman P: Polyhenols and disease risk in epidemiological studies. Am J Clin Nutr 2005, 81:317S-325S.

34. Rievere C, Nguyen V, Pieters L, Dejaegher B, Heyden Y, Minh C: Polyphenols isolated from antiradical extracts of Mallotus metcalfianus. Phytochemistry 2009, 70:86-94.

35. De-Lucca A, Cleveland T, Rajasekara K, Boue S, Brown R: Fungal Properties of CAY-1, a Plant Saponin, for Emerging Fungal Pathogens. In 45th Interscience Conference in Antimicrobial Agents and Chemotherapy Abstract. Washington, D.C: ARS, Food and Feed Safety Research; 2005:180.

36. Wijayani W: Sitotoksisitas Minyak Atsiri Biji dan Daging Buah Mahkota Dewa (Phaleria macrocarpa [Scheff.] Boerl.) Terhadap Myeloma Cell Line dan HeLa Cell Line Serta Identifikasi Senyawa Minyak Atsiri dengan Kromatografi Gas-Spektrometri Massa (GC-MS). Yogyakarta: Skripsi FMIPA UGM; 2005:41-50.

37. Rohyami Y: Penentuan Kandungan Flavonoid dari Ekstrak Metanol Daging Buah Mahkota Dewa [Phaleria macrocarpa (Scheff) Boerl]. J Logika 2009, 5(1):5-8.

38. Tambunan RM, Simanjuntak P: Determination of chemical structure of antioxidant compound benzophenon glycoside from n-butanol extract of the fruits of Mahkota Dewa [Phaleria macrocarpa (Scheff) Boerl.]. Majalah Farmasi Indones 2006, 17(4):184-189.

39. Faried A, Kurnia D, Faried LS, Usman N, Miyazaki T, Kato H, Kuwano H: Anticancer effects of gallic acid isolated from Indonesian herbal medicine, Phaleria macrocarpa (Scheff.) Boerl, on human cancer cell lines. Int J Oncol 2007, 30:605-613.

\section{doi:10.1186/1472-6882-14-152}

Cite this article as: Lay et al:: Phytochemical constituents, nutritional values, phenolics, flavonols, flavonoids, antioxidant and cytotoxicity studies on Phaleria macrocarpa (Scheff.) Boerl fruits. BMC Complementary and Alternative Medicine 2014 14:152. 